\title{
Comparison of Spatial Ability Between Male and Female Athletes
}

\author{
Azkane Adilla Putri, ${ }^{1}$ Leonardo Lubis, ${ }^{2}$ Paulus Anam $0{ }^{3}{ }^{3}$ \\ ${ }^{1}$ Faculty of Medicine, Universitas Padjadjaran, ${ }^{2}$ Department of Anatomy, Cell Biology and \\ Physiology Faculty of Medicine Universitas Padjadjaran, ${ }^{3}$ Department of Neurology Faculty of \\ Medicine Universitas Padjadjaran/Dr. Hasan Sadikin General Hospital Bandung
}

\begin{abstract}
Background: Spatial ability is the ability to understand and memorize spatial relationship beneficial objects. This domain of cognition is crucial in sport activity for deciding strategy. Sex is one of the factors that determine spatial ability. This study aimed to determine the comparison of spatial ability between male and female athletes.

Methods: This cross-sectional study was conducted by non-pairing comparative method. Data were taken on September 2015 in Indonesian National Sport Committee (Komite Olahraga Nasional Indonesia, KONI) Sport Center, Bandung, West Java, Indonesia. Spatial instrument used was Spatial Ability Test 1. Subjects were recruited from athletes of KONI, West Java, aged between 19-27 years old who were being trained for 19th National Sports Weeks (Pekan Olahraga Nasional, PON XIX) 2016. Mean value between male and female were compared using studies T-test with significance value $(\mathrm{p})<0.05$.
\end{abstract}

Results: The total samples were 95 subjects, consisting of 44 males and 51 females. Results of the mean value in male were $29.16( \pm 3.48)$ and female $28.80( \pm 3.74)$. By using studies T-test, the significance outcome found was $\mathrm{p}=0635(\mathrm{p}>0.05)$.

Conclusions: There is no spatial ability differencesbetween male and female athletes of KONI, West Java

Keywords: Athletes, gender, spatial ability

\section{Introduction}

Spatial ability defined as ability to visualize and imagine an object into 3-dimensional form and understand the relationship of the surrounding object.1,2 Its benefits are seen in daily activities such as reading map, navigating and detecting objects. ${ }^{1,2}$ It is needed in some parts of mathematics, science, technic, economy, meteorology, architecture, aeronautic and medicine. ${ }^{1,2}$ Spatial ability is also important in sports. Athletes need this ability to balance their psychomotor ability and physical fitness in deciding strategy used in a match, in which it is important for their achievements.

Spatial ability is determined by several factors; one of them is sex, in which determining brain differences in anatomy, and physiology such as hippocampus lateralization, volume of inferior parietal lobe, and androgen hormone level. ${ }^{3-9}$ These differences are still contradiction. Several studies had reported differences and other studies had reported no differences at all.,10-11 However, it is not known whether occupation or daily activities influence spatial ability, such as what is happened to in athletes.

This study was conducted to analyze the comparison of spatial ability between male and female athletes on Indonesian National Sport Committee (Komite Olahraga Nasional Indonesia, KONI), West Java, Indonesia.

\section{Methods}

This study was a cross sectional study performed using non-pairing comparative method, held on September 2015 in KONI Sport Center, Bandung, West Java, Indonesia. This study had been approved by The Health Research Ethics Committee, Faculty of Medicine, Universitas Padjadjaran, Bandung, No: 519/UN6.C1.3.2/KEPK/PN/2015.

This study was conducted on KONI athletes in West Java, consisted of 12 sport divisions

Correspondence: Azkane Adilla Putri, Faculty of Medicine, Universitas Padjadjaran, Jalan Raya Bandung-Sumedang Km.21, Jatinangor, Sumedang, Indonesia, Phone: +62 85720000593 Email: azkaneadillap@gmail.com 
Table 1 Characteristics of Subjects

\begin{tabular}{lcc}
\hline & $\mathbf{N}(\%)$ & Mean $\mathbf{( \pm S D )}$ \\
\hline Sex & & \\
$\quad$ Male & $44(53.7)$ & \\
$\quad$ Female & $51(46.3)$ & $22.35( \pm 0.82)$ \\
Body Massa Index (BMI) & & \\
Blood Pressure & & $118.75( \pm 1.85)$ \\
$\quad$ Systole & & $72.43( \pm 1.30)$ \\
$\quad$ Diastole & & $65.07( \pm 3.09)$ \\
Heart Rate & & $21.23( \pm 2.85)$ \\
Respiratory Rate & & \\
\hline
\end{tabular}

(fencing, athletics, wrestling, judo, kempo, weightlifting, archery, sport climbing, martial arts, gymnastic, taekwondo, and boxing), who were being specially trained for the19th National Sports Weeks (Pekan Olahraga Nasional, PON XIX) 2016. By using comparative analytic unpaired test sample size formula with $\alpha=5 \%$ and $\beta=95 \%$, it was known that minimum sample number were 32 for every sex group.

Informed consent has been obtained. Data taken were further identified based on inclusion criteria such as aged between 19 to 27 years old, had minimum high school level of education or equal and good physical condition prior to the test. Athletes who disqualified during the test were excluded from this study. From 200 data taken, finally 95 subjects fulfilled inclusion criteria, consist of 44 males and 51 females.

Data regarding spatial ability used were primary data acquired by Spatial Ability Test I (Newton and Bristoll) that had been translated and modified. The validation and reliability $(\alpha=0.704)$ were performed by 30 subjects which had similar characteristics with samples. Instrument was divided into 45 visual questions that had to be done as many as possible within 20 minutes. Data used on calculation were male's and female's spatial ability score processed by statistic software.
Data normality test with Kolmogorov-Smirnov test $(n>50)$ was performed on female group, while Shapiro-Wilk $(n<50)$ was performed on male group. Mean value between male and female were compared using studies T-Test in well-distributed data. Test result significances were determined by $p$ value $(p<0.05)$.

\section{Results}

Characteristics of samples found the quantity of female was more than male. Based on physical examination performed by KONI medical team, the samples had a good condition.

Results of normality test on both male and female group revealed well-distributed data, thus mean was use as central measurement and standard deviation as distribution measurement.

Due to well-distributed data, T-Test was used to analyze differences spatial ability between male and female. Significance outcome developed were $p=0.635 \quad(p>0.05)$ which revealed no spatial ability differences between male and female on athletes of KONI, West Java.

\section{Discussions}

Spatial ability is divided into three parts:

Table 2 Score of Spatial Ability Test

\begin{tabular}{lll}
\hline & \multicolumn{3}{c}{ Spatial Ability } \\
\cline { 2 - 3 } & Mean & SD \\
\hline Male & 29,16 & 3,48 \\
Female & 28,80 & 3,74 \\
\hline
\end{tabular}


spatial visualization, spatial perception, and mental rotation. ${ }^{3}$ To understand comparison between sex towards spatial ability, we cannot only see one aspect. ${ }^{3}$ Instrument used in this study represents these three aspects generally. On the other hand, there are a lot of instruments that can be used for one or more specific aspects. ${ }^{8-11}$

Spatial ability is specifically recognized by several brain areas. Parietal lobe is one of brain areas that plays a role in spatial ability. ${ }^{5}$ Previous study discovered that monkeys with lesions in the parietal lobe had lower spatial ability. ${ }^{5}$ After controlling brain surface area, males were known to have bigger surface area on parietal lobe compared to females. ${ }^{5}$

In addition to parietal lobe, hippocampus also has a role in spatial ability. ${ }^{12}$ Other previous study found that hippocampus had greater activity in spatial ability. ${ }^{12}$ It can be seen using functional Magnetic Resonance Imaging (fMRI). ${ }^{12}$ Uniquely, hippocampusis is more connected with parietal lobe on male, and temporal lobe on female. ${ }^{9}$

Androgen hormone is mentioned as one of the important factors affecting spatial ability. ${ }^{3,7-8}$ Androgen plays a role on hippocampus cell formation and development during prenatal period. ${ }^{6}$ Unfairly, androgen effect wismore prominent in the right hemisphere development. ${ }^{4}$ It is also known that normal androgen level is higher on male than female. ${ }^{3,7-8}$ This is one of the theories contributing that showed male's brain is more right hemisphere-lateralized, in which right hemisphere is a functional brain area taking a big role on spatial ability.,

Based on the factors, there is a possibility that spatial ability on males is higher than females. However, the result of this study does not fit the theories. In addition, this study is not in line with the previous study that was conducted on patrilineal. It might be influenced by education level..$^{10}$ Spatial ability was one aspect of academic, so that higher education level would result in higher spatial ability. ${ }^{10}$ Beside of education level, type of education might also influence spatial ability. It is known that spatial ability correlates more with natural science especially with mathematics. ${ }^{7}$

In the other studies that performed in three categories of sports, males had better spatial ability on average compared to females in all categories.However, there are different significances on each category. ${ }^{11}$ There are significant differences between low risk sports activity (running, athletics, and gymnastic) and high risk sports activity (parachuting, scuba diving, skiing, and mountain climbing), while on moderate risk sports activity (football, basketball, and handball), there is no significant difference. ${ }^{11}$ It might be caused by different characteristics on sport spectrum influencing cognitive functions molecularly, cellularly and behaviorally. ${ }^{13}$

Based on significance of the results, males had higher averages, it was in line with previous studies on volleyball and tennis athletes. There were no significant spatial ability differences between male and female with same performance and training experiences. ${ }^{8}$ It is assumed that spatial ability might be influenced by sport activity. ${ }^{8}$ Sport activity is considered could increase circulating androgens level and later can shrink sex gap between them. ${ }^{8}$ Increased levels of androgen could improve spatial ability on female, but could inhibit spatial ability on male. ${ }^{6,8}$

Androgen hormone effect is also seen on congenital adrenal hyperplasia $(\mathrm{CAH})$ patients, in which adrenal gland produces excess testosterone during prenatal development.6 Excess adrenal androgen is provided by $\mathrm{CAH}$ increases spatial ability on female and reduces spatial ability on male, so it is concluded that moderate androgen level might influence spatial ability optimally. ${ }^{6}$

This study has limitations. There were confounding factos that contribute to the result of this study. Environmental factors are one of the most important factors on cognitive function. Biopsychosocial model showed how biology and environment make causative effect. ${ }^{7}$ For example, differences in brain might alter on how people think and choose their environment, and environment would alter biological development further. ${ }^{7}$ Examples of environmental factors include education level, economical state, culture, use of medication, marital status, and stress. ${ }^{7,10,14}$ It is recommended to control those factors in further studies.

The result of this study shows that there was no spatial ability differences between men and women in athletes of KONI, West Java. It might be caused by environmental factors influencing, which were not controled in this study. In addition, further studies need to be conducted to know the effect of specific sport on spatial ability.

The result of this study can be used as benchmark for athletes to receive specific exercise program in order to improve spatial ability that can increase athletes performance and athletes achievement 


\section{References}

1. Yilmaz HB. On the development and measurement of spatial ability. IEJEE. 2009;1(2):83-96.

2. Ramirez G, Gunderson EA, Levine SC, Beilock SL. Spatial anxiety relates to spatial abilities as a function of working memory in children. Q J Exp Psychol (Hove). 2012;65(3):474-87.

3. Matlin M. Cognitive psychology. 7th ed. New Jersey: John Wiley \&Sons; 2009.

4. Frings L, Wagner K, Unterrainer J, Spreer J, Halsband U, Schulze-Bonhage A. Genderrelated differences in lateralization of hippocampal activation and cognitive strategy. Neuroreport. 2006;17(4):41721.

5. Elias LJ, Saucier DM. Neuropsychology: clinical and experimental foundations. New York: Pearson; 2006.

6. Puts DA, McDaniel MA, Jordan CL, Breedlove SM. Spatial abilty and prenatal androgen: meta-analyses of congenital adrenal hyperplasia and digit ratio (2D:4D) studies. Arch Sex Behav. 2008;37(1):10011.

7. Miller DI, Halpern DF. The new science of cognitive sex differences. Trends Cogn Sci. 2014;18(1):37-45.
8. Notanircola A, Maccagnano G, Pesce V, Tafuri S, Novielli G, Moretti B. Visualspatial capacity: gender and sport differences in young volleyball and tennis athletes and non-athletes. BMC Res Notes. 2014;7(1):57.

9. Persson J, Spreng RN, Turner G, Herlitz A, Morell A, Stening E,et al. Sex differences in volume and structural covariance of the anterior and posterior hippocampus. Neuroimage. 2014;99(1)215-25.

10. Hoffman M, Gneezy U, List JA. Nurture Affects gender differences in spatial abilities. PNAS. 2011;108(36):14786-88.

11. Hromatko I, Butkovic A. Sensation seeking and spatial ability in athletes: an evolutionary account. Journal of Human Kinetics. 2009;21(1):5-13.

12. Viard A, Doeller CF, Hartley T, Bird CM, Burgess N. Anterior hippocampus and goal-directed spatial decision making. J Neurosci. 2011; 31(12):4613-21.

13. Thomas M. The effect of different movement exercises on cognitive and motor abilities. Advance in Physical Education. 2012;2(4):172-8.

14. Weber D, Skirbekk V, Freund I, Herlitz A. The changing face of cognitive gender differences in europe. PNAS. 2014;111(32):11673-8 